\title{
Trends and variability of temperature and evaporation over the African continent: Relationships with precipitation
}

\author{
Charles ONYUTHA \\ Department of Civil and Environmental Engineering, Kyambogo University, P.O. Box 1, Kyambogo, Kampala, Uganda. \\ Email: conyutha@kyu.ac.ug
}

Received: October 30, 2019; accepted: July 2, 2020

\section{RESUMEN}

Se analizan cambios a largo plazo (1901-2015) en los valores mensuales de evapotranspiración potencial (PET, por sus siglas en inglés), precipitación, y temperaturas mínima $\left(\mathrm{T}_{\min }\right)$ y máxima $\left(\mathrm{T}_{\max }\right)$ en África para cuantificar las tendencias y valorar la covariabilidad de dichos parámetros climáticos. Se analizaron las tendencias tanto al calentamiento como a la sequía en todo el continente. El calentamiento en el periodo 1979-2015 fue mayor que de 1901 a 1940. Entre 1940 y mediados de la década de 1970 se observó una leve tendencia al enfriamiento. En el periodo 1901-2015 los valores anuales promedio de $\mathrm{T}_{\max }, \mathrm{T}_{\min } \mathrm{y}$ PET en África muestran una tendencia al calentamiento y la sequía a tasas de $0.18^{\circ} \mathrm{C}, 0.22{ }^{\circ} \mathrm{C}$ y $3.5 \mathrm{~mm}$ por década, respectivamente. De 1961 a 1990 la precipitación anual promedio de todo el continente mostró una tendencia a la sequía a una tasa de alrededor de $-28 \mathrm{~mm}$ por década. Si se considera el periodo 1961-2015, la precipitación disminuyó a una tasa de alrededor de $-8 \mathrm{~mm}$ por década. De 1901 a 1915 , algunas áreas alrededor del Lago Victoria en África oriental y a lo largo de la costa occidental al sur del ecuador registraron tasas de incremento en la precipitación de alrededor de $36 \mathrm{~mm}$ por década. Tanto en Sudán como en África del Sur y África del Norte se observaron tendencias significativas $(\mathrm{p}<0.01)$ al calentamiento. En la región de clima Mediterráneo cálido y la parte occidental de Sudáfrica se registraron tendencias positivas y significativas de PET $(\mathrm{p}<0.01)$. Es posible que el incremento y la disminución a largo plazo de la temperatura y la precipitación (respectivamente) a lo largo de África del Norte sean indicativos de la expansión del desierto del Sahara con el tiempo. Con excepción de las regiones con clima desértico cálido se registró una alta variabilidad de la precipitación en el continente. Las zonas con clima ecuatorial registraron bajas temperaturas y variabilidad de la PET. La mayor correspondencia entre precipitación y temperatura se registró en múltiples escalas (6-8 años). Las correlaciones entre precipitación y PET (o temperatura) fueron negativas y débiles $(\mathrm{p}>0.01)$ en su mayor parte. Dado que la sensibilidad de $\mathrm{T}_{\min }$ a los factores locales es mayor que la de $\mathrm{T}_{\max }$, las zonas con una correlación negativa fuerte fueron mayores para $T_{\max }$ que para $T_{\min }$. Estos resultados indican que es necesario establecer medidas planificadas para enfrentar la inseguridad alimentaria en el África subsahariana.

\section{ABSTRACT}

This study analyzes changes in the long-term (1901-2015) monthly values of potential evapotranspiration (PET), precipitation, and minimum $\left(\mathrm{T}_{\min }\right)$ and maximum $\left(\mathrm{T}_{\max }\right)$ temperatures across Africa to quantify trends and assess covariability between these climatic variables. Both warming and drying trends were observed across the continent. The 1979-2015 warming was stronger than that from 1901 to 1940. Some cooling occurred from 1941 to the mid-1970s. The 1901-2015 annual $\mathrm{T}_{\max }, \mathrm{T}_{\min }$, and PET averaged over Africa exhibited increasing or drying trends across the continent at rates of $0.18{ }^{\circ} \mathrm{C}, 0.22^{\circ} \mathrm{C}$, and $3.5 \mathrm{~mm}$ per decade, respectively. The 1961-1990 annual precipitation averaged over the whole continent showed that Africa experienced drying at a rate of about $-28 \mathrm{~mm}$ per decade. When considering the period 1961-2015, the rate of precipitation decrease was about $-8 \mathrm{~mm}$ per decade. From 1901 to 1915, areas around Lake Victoria in East Africa and along the western coastline south of the equator experienced wetting rates of up to $36 \mathrm{~mm}$ per decade. Significant 
( $p<0.01)$ warming trends occurred in Sudan, Southern and Northern Africa. Positive PET trends were significant $(\mathrm{p}<0.01)$ in the warm Mediterranean climate, and the western part of South Africa. Long-term temperature increase and precipitation decrease across northern Africa possibly indicated the Sahara Desert expansion over time. Except in the warm desert climate, the continent exhibited high precipitation variability. Equatorial climate experienced low temperature and PET variability. The strongest coherence between precipitation and temperature existed at multiple scales (6-8 years). Correlations between precipitation and PET (or temperature) were mostly negative and weak $(\mathrm{p}>0.01)$. Because the sensitivity of $\mathrm{T}_{\min }$ to local influences is higher than that of $\mathrm{T}_{\max }$, areas with strong negative correlation were larger in coverage for $\mathrm{T}_{\max }$ than those of $\mathrm{T}_{\min }$. These results call for planned measures to tackle food insecurity in sub-Saharan Africa.

Keywords: climate variability, temperature trends, precipitation trends, evapotranspiration trends, seasonal CSD trend, hydroclimate of Africa.

\section{Introduction}

Due to anthropogenic forcing, the 21st century warming will be strong in Africa (IPCC, 2013). This signals a worrying situation for efforts aimed at tackling the food insecurity challenge, especially in the sub-Saharan region, where subsistence heavily depends on smallholder farming. Several studies have been conducted on changes in hydroclimatic variables such as temperature, potential evapotranspiration (PET), and precipitation (Pcp) in Africa for planning of predictive adaptation to the impacts of climate variability on hydrometeorology and agrometeorology (among others, Beltrando and Camberlin, 1993; King'uyu et al., 2000; Nicholson, 2000; Grist and Nicholson, 2001; Kruger and Shongwe, 2004; Kizza et al., 2009; Morishima and Akasaka, 2010; Nyeko-Ogiramoi et al., 2013; Ozer and Mahamoud, 2013; MacKellar et al., 2014; Mekasha et al., 2014; Moron et al., 2016; Oloruntade et al., 2016; Camberlin, 2017; Ahokpossi, 2019; Nashwan and Shahid, 2019; Bush et al., 2020; Mubialiwo et al., 2020; Onyutha, 2020). However, most of these studies: $(i)$ were conducted over small areas using short-term data selected over different periods, (ii) focused on analyses of trends or variability but not both, (iii) did not consider changes in Pcp, PET, and temperature in a single research work, (iv) made use of series aggregated to seasonal (for instance, March-April-May, June-July-August) blocks, ( $v$ ) did not consider the effect of seasonality and long-term persistence on trend results, and ( $v i$ ) did not examine the cross-correlation between temperature, Pcp, and PET.

The detection of trends in Pcp, PET and temperature tends to be affected by the variability of the data. Superimposed cycles of natural cyclical variability could be misinterpreted as a monotonic trend (Jain and Lall, 2001; Onyutha, 2016a; Armal et al., 2018). Such an effect can be amplified by uncertainty due to the finite sample size. Regarding trend analyses, it is known that the longer the data, the better the results. However, "the period referred to as the socalled 'long-term' is so subjective that the question of what data record length gives bias-free trend results cannot be clearly answered" (Onyutha et al., 2016). The presence of a significant monotonic trend in long-term data may indicate the impact of some external forcing on the system. Therefore, when the data has a significant trend, detrending should be done and detrended series used for variability analyses. In short, variability should also be quantified alongside trend analyses for planning predictive adaptation. Furthermore, data from some months can have apparent linear increases or decreases while the null hypothesis $H_{0}$ of no trend may be rejected based on series aggregated at annual or seasonal time scales. The possible heterogeneity of trends among monthly data can render ambiguous conclusions made on trends detected using annual data. In the same vein, although $H_{0}$ of natural randomness can be apparently rejected for data of some months, it may not be rejected for the series of a given year or season. Above all, at the time of writing this paper, no previous studies were found to be conducted on a monthly timescale to examine the covariation of subtrends in Pcp, PET or temperature considering the entire African continent.

The importance of investigating the covariation of Pcp with PET or temperature can be considered in two ways. Firstly, analyses of possible large-scale ocean-atmosphere drivers of Pcp across the African continent were already conducted in studies such as Onyutha (2018a), Maidment et al. (2015), and 
Nicholson and Selato (2000). Therefore, possible influences of the variation in large-scale ocean-atmosphere conditions on the variability of hydroclimatic variables such as temperature and PET can be inferred from the drivers of Pcp. This can be important to predict upcoming periods of warming and drying in the various regions of the African continent. Secondly, it provides an insight into the changes in water budget estimates, especially for arid and semiarid regions. In arid regions, the annual Pcp is always less than the annual PET. It may be vital to note that semiarid and humid ecosystems are mainly driven by the changes in Pcp. Environmental changes such as depletion of groundwater, desertification, soil erosion, and woody plant encroachment, alongside the high variability in Pcp, largely affect the ecohydrology of water-limited ecosystems in arid regions. Linkage between Pcp and PET across arid regions enhances our understanding of how water controls can influence the plant community composition, function, and structure. For the Mediterranean climate, shrubland ecosystems tend to be vulnerable to increasing temperature and reduced water availability (Usodomenech et al., 1995). Nevertheless, due to global warming or increasing temperature, the evaporative demand was projected by an IPCC assessment to increase almost everywhere (Bates et al., 2008). The implications of this projection (e.g., for ecosystems) vary across climatic regions. In other words, some regions may be disproportionately affected by the impacts of climate change and variability. Given the wide variety of climatic regions across Africa, predictive adaptation requires comprehension of the directions and magnitudes of observed or historical trends in temperature, PET and Pcp across the entire continent.

Therefore, this study aimed at using long-term (1901-2015) monthly Pcp, temperature, and PET on a spatial grid of $0.5^{\circ} \times 0.5^{\circ}$ resolution covering all the countries of the African continent (see Fig. SM-1a in the supplementary material) to: (i) quantify trend directions and magnitudes at a monthly time scale, and (ii) examine the covariation of Pcp along with temperature and PET. This was done while considering the effects of seasonality and persistent fluctuations in the series on the results of the analyses.

\section{Materials and methods}

\subsection{Data}

The Climatic Research Unit (CRU) Time-Series (TS) v. 4.0 (Harris et al., 2014) for the period 19012015 was downloaded in gridded form $\left(0.5^{\circ} \times 0.5^{\circ}\right)$ from https://crudata.uea.ac.uk/cru/ (accessed: June 18, 2017). The downloaded CRU TS4.0 data comprised minimum $\left(\mathrm{T}_{\min },{ }^{\circ} \mathrm{C}\right)$ and maximum $\left(\mathrm{T}_{\max },{ }^{\circ} \mathrm{C}\right)$ temperatures, as well as Pcp and PET (mm). Each variable was at a monthly temporal resolution.

The PET $\left(\mathrm{mm} \mathrm{day}^{-1}\right)$ data of the CRU TS4.0 (Harris et al., 2014) was computed using a variant of the Penman-Monteith method (Allen et al., 1994) based on half degree gridded vapor pressure $(\mathrm{hPa})$, wind speed $\left(\mathrm{m} \mathrm{s}^{-1}\right)$, cloud cover $(\%)$, and absolute values of $\mathrm{T}_{\max }, \mathrm{T}_{\min }$, mean temperature $\left({ }^{\circ} \mathrm{C}\right)$, and wind speed $\left(\mathrm{m} \mathrm{s}^{-1}\right)$. The monthly PET total $(\mathrm{mm})$ used in this study is a sum of the daily PET values for each month.

The CRU datasets used in this study were obtained from gauge interpolations. Several areas across Africa (especially in sub-Saharan Africa) lack dense weather stations. Furthermore, several weather stations are not continuously operated due to poor maintenance of data recording or observation equipment coupled with interruptions by political turmoil (Onyutha, 2018b). The accuracy of interpolation products depends on the number of gauge stations in a particular location. Therefore, the accuracy of results and the ranges of uncertainty vary across the continent.

Obtaining reliable estimates of evaporation (or flow of water from land to the atmosphere) remains a challenging task. Estimating evaporation using the distributed model requires a high resolution spatio-temporal description of land use and land cover types, and these spatial data are not always available. In some cases, estimates of terrestrial evaporation are made from satellites: however, the flux of terrestrial evaporation cannot be directly sensed from satellites (Martens et al., 2017). Nevertheless, advances have been made in the improvement of evaporation estimates over large scales. Some examples include data-driven estimates of global land evapotranspiration from 1982 to 2008 (Jung et al., 2010), understanding the response of terrestrial evaporation to teleconnection patterns (Martens et al., 2018), and the Global Land Evaporation Amsterdam Model (GLEAM) datasets (Miralles et al., 2011; Martens et al., 2017), downloadable from 
https://www.gleam.eu/ (accessed: June 14, 2020); however, evaporation datasets based on satellite information are normally comprised by short-term records. The CRU TS4.0 datasets were adopted for this study because of their reliability and long-term records gridded at a spatial $\left(0.5^{\circ} \times 0.5^{\circ}\right)$ scale covering the entire African continent. Since the number of weather stations influences interpolation products at a given location, spatial similarities of results from analyses based on the CRU TS4.0 data should not be assessed at the level of individual locations, but over a region or large area (Onyutha, 2018a).

The data at grid points over land were thoroughly checked and confirmed to have no missing values. The various countries within the continent can be seen in Figure SM-1 of the supplementary material. The longterm mean of the data used in this study can be seen in Figures SM-2 to SM- 6 of the supplementary material.

\subsection{Trend analyses}

To consider the influence of seasonality (here, a season is taken as a month) on the results of trend analyses, two steps should be taken: (1) the trend statistic values are computed separately for each month, which is done for both trend directions and magnitudes, and (2) trend results for the various months are combined into an overall or global trend measure.

\subsubsection{Seasonal trend directions}

To detect monotonic trends, a method that uses cumulative sum of differences (CSD) between exceedance and non-exceedance counts of data points (Onyutha, 2016b) was used. The details of this method can be seen in section SM-1.1 of the supplementary material.

Analyses of trend directions were carried out in three steps. Firstly, the seasonal CSD trend test was conducted using data (or $\mathrm{T}_{\max }, \mathrm{T}_{\min }, \mathrm{PET}$, and Pcp) at each grid point. In the second step, the CSD trend test was separately conducted to test $H_{0}$ using data of each month. Thirdly, the cumulative effects of temporal variations in the full time series of $T_{\max }, T_{\min }$, PET, and Pcp were graphically assessed using series averaged over all the grid points on land mass across the continent. To do so, the following procedure was considered: $(i)$ at each grid point, data of a particular month was separately extracted from the full time series, (ii) for a particular year (e.g., 1901), the average of data for a given month (such as January) across all the grid points was computed, and (iii) as step (ii) but separately repeated for each month.

\subsubsection{Trend magnitudes}

The linear trend slope in the data of each month at a given grid point was computed using a non-parametric approach (Theil, 1950; Sen, 1968), whose details can be found in section SM-1.2 of the supplementary materials. The trend magnitudes obtained based on $\mathrm{T}_{\max }$ from the various months were averaged. The averaging procedure was repeated for $\mathrm{T}_{\min }$, PET, and Pcp.

\subsection{Variability analyses}

There are two ways in which variability can be quantified to test $H_{0}$ of natural randomness using the CSD method, namely the use of variability CSD statistic and temporal variation of CSD-based subtrends.

\subsubsection{CSD variability statistic}

The first step in the analyses of variability is quantifying the trend in long-term data. If $H_{0}$ is rejected at $\alpha$, the series is first detrended. In this case, the CSDbased variability (Onyutha, 2018a) can be quantified in the detrended series. If $H_{0}$ is not rejected at $\alpha$, there is no need to perform detrending, and variability can be quantified using the original data.

To derive the CSD variability statistic, the differences between exceedance and non-exceedance counts of data values in the series resulting from the first step are obtained. The number of times that the rescaled series crosses the reference or long-term mean is obtained as the variability statistic. From this, the standardized CSD statistic $Z^{*}$ is computed. Based on a two-tailed test and using $Z_{\alpha / 2}$ (which denotes the standardized normal variate at the selected $\alpha), H_{0}$ can be rejected if $\left|Z^{*}\right| \geq Z_{\alpha / 2}$; otherwise, $H_{0}$ is not rejected.

In this study, $H_{0}$ was tested using $\mathrm{T}_{\max }, \mathrm{T}_{\min }$, PET, and Pcp at each grid point. The variability was categorized as very high, high, moderate, low, and very low for statistic $Z^{*}$ values in the ranges $0-1.63$, $1.64-1.95,1.96-2.57,2.58-2.80, \geq 2.81$, respectively. The details of the procedure on how to test $H_{0}$ using the CSD variability statistic can be found in section SM-2.1 of the supplementary material.

\subsubsection{Temporal variation in subtrends}

$H_{0}$ was also tested using values of sub-trend statistics. To compute temporal subtrends in a given series 
using the CSD-based method, $H_{0}$ of no trend is tested in the long-term data. If $H_{0}$ is rejected, detrending of data is done and the CSD-based method of quantifying variability is applied to the detrended data. If $H_{0}$ is not rejected at $\alpha$, the CSD method is applied to the original data.

In the next step, a particular time scale is chosen such as 5, 10, and 15 years for annual data. The choice of the time scale depends on the purpose of the study. For instance, to assess climate fluctuations, the time scale can be set to about 30 years. However, this study considered a 15-year time scale to assess multi-decadal variability in subtrends. The 15 -year data period is relevant as the designed life for some water supply systems in an irrigation scheme (Onyutha, 2016c), water supply projects or risk-based water resources applications (Onyutha, 2018a). A chosen time slice (in this case 15 years) is moved from the beginning to the end of the series. Over each time slice, the CSD trend statistic $Z$ is computed. The variability of the subtrends is obtained in terms of the variation of $Z$ values within the corresponding time (for instance, a year) of observation (Onyutha, 2018a). To test $H_{0}$, of natural randomness, variability thresholds at the selected $\alpha$ can be constructed using $\pm Z_{\alpha / 2}$. If all the $Z$ values fall within the thresholds, $H_{0}$ is not rejected; otherwise, it is rejected. Further crucial clarification on the CSD method for variability analyses based on temporal changes in subtrends can be found in section SM-2.1.1 of the supplementary material. These procedures can be found implemented in the CSD-variability analyses tool (CSD-VAT), which is freely downloadable from https://sites.google.com/site/conyutha/tools-to-download (accessed: August 18, 2019).

\subsubsection{Comparison of Pcp subtrends with $T_{\max }, T_{\min }$, and PET subtrends}

At each grid point, the CSD sub-trend statistic values were computed using $\mathrm{T}_{\max }, \mathrm{T}_{\min }, \mathrm{PET}$, and Pcp considering the entire period 1901-2015. Covariability of subtrends from the climatic variables $\left(\mathrm{Pcp}, \mathrm{T}_{\max }\right.$, $\mathrm{T}_{\text {min }}$, and PET) was quantified by testing $H_{0}$ of no correlation using Pearson correlation.

\subsubsection{Wavelet coherence}

The association of $\mathrm{T}_{\max }, \mathrm{T}_{\min }$ and PET variations with Pcp variability was assessed in terms of wavelet coherence. Pcp, $\mathrm{T}_{\max }, \mathrm{T}_{\min }$, and PET were converted from monthly to annual series and averaged over the entire continent. Prior to the application of wavelet coherence, each series was standardized through subtraction of the mean and division by the standard deviation. Based on bivariate wavelet analysis, wavelet coherence estimates a correlation measure between any two given series at all the periodicities through time. Wavelet coherence was computed for six combinations of the climatic variables including Pcp and $\mathrm{T}_{\max }$, Pcp and $\mathrm{T}_{\min }, \mathrm{Pcp}$ and PET, $\mathrm{T}_{\max }$ and $\mathrm{T}_{\min }, \mathrm{PET}$ and $\mathrm{T}_{\min }$, and PET and $\mathrm{T}_{\max }$. Continuous wavelet transform was applied to each of the combinations to find regions in time frequency where the two-time datasets under consideration covary. A total of 1000 Monte Carlo randomizations were used to assess the coherence significance.

\section{Results}

\subsection{Trends and variability \\ 3.1.1 Trends}

Time series plots for Pcp and PET (Fig. 1a-e) were made using data extracted at a number of locations from different climatic conditions in the continent, including warm semi-arid climate (WSAC), warm desert climate (WDC), equatorial climate (EC), humid sub-tropical climate (HSTC), and cold semi-arid climate (CSAC). The Pcp average from the different climate types can be seen in Figure 1f. The location (longitude and latitude) at which the data for WSAC, WDC, EC, HSTC, and CSAC were extracted was $\left(-11.25^{\circ}, 13.25^{\circ}\right),\left(1.25^{\circ}, 24.25^{\circ}\right),\left(20.25^{\circ}, 0.25^{\circ}\right)$, $\left(24.75^{\circ},-15.75^{\circ}\right)$, and $\left(25.75^{\circ},-27.75^{\circ}\right)$, respectively. What is noticeably common for the data of different climate types is the positive trend in PET (Fig. 1a-e) from around 1985 to 2015 (end of data). Furthermore, the decrease in Pcp (Fig. 1a-d) from around 1960 to the end of the data period is also generally evident across the different climate types. At some locations (see Fig. 1c, e) series before 1940 showed minimal deviations from a certain constant value, which could be due to a data quality problem. It is possible that such locations had only a few weather stations before 1940. For the desert climate (Fig. 1b), annual Pcp was generally lower than for other types of climate.

Trends results in each month's data can be observed in Figures SM-7 to SM-14 of the supplementary material. Figure 2 was obtained based on the trends 

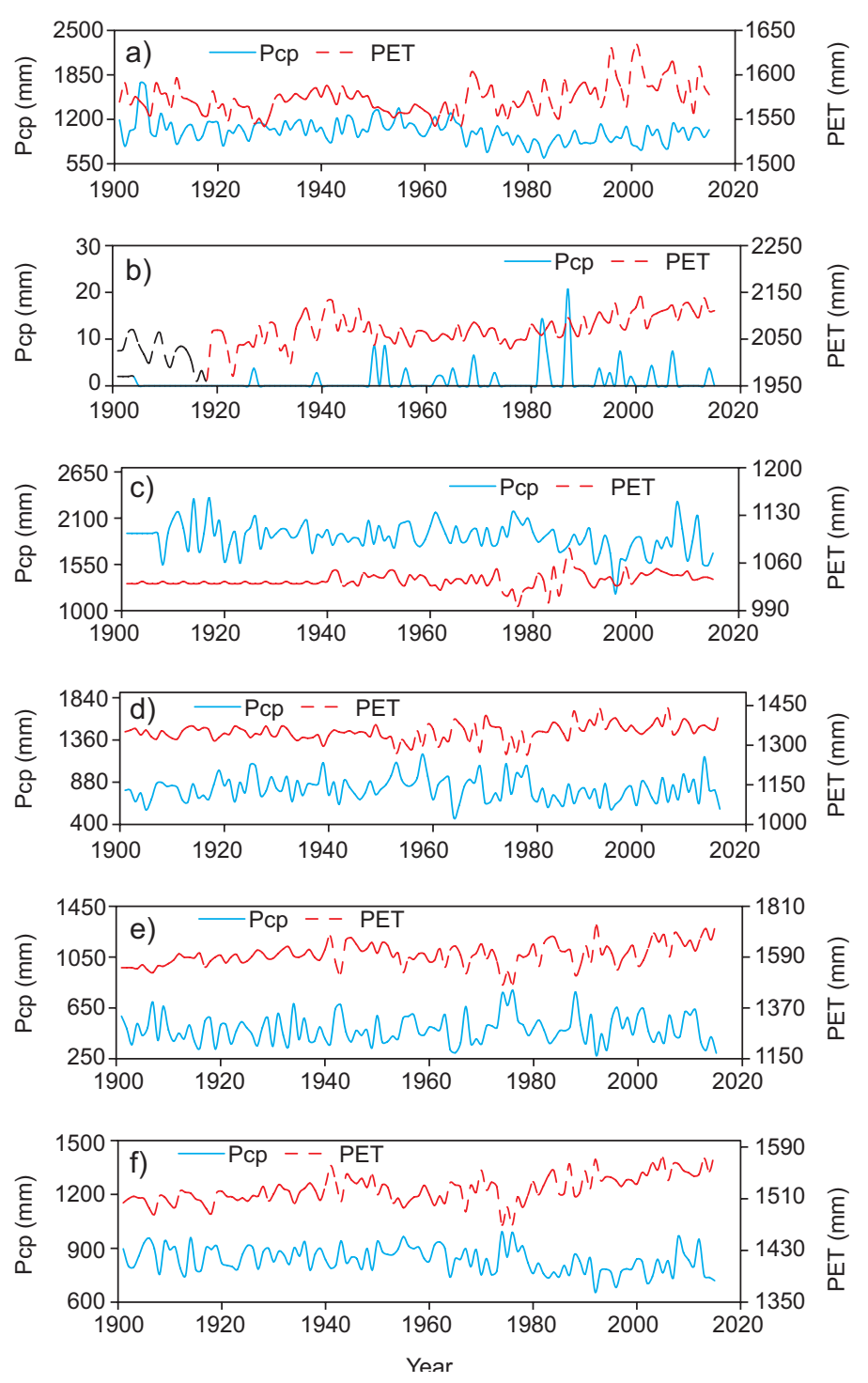

Fig. 1. Temporal variation of annual Pcp and PET for: (a) warm semi aridclimate, (b) warm desert climate, (c) equatorial climate, (d) humid subtropical climate, and (e) cold semiarid climate, (f) average of (a) to (c) data.

results of the various months. In general, the entire African continent (except Madagascar) was characterized by warming trends with respect to $T_{\min }$ and $\mathrm{T}_{\text {max }}$. Large increases in both $\mathrm{T}_{\max }$ and $\mathrm{T}_{\min }$ at rates between 0.08 and $0.25{ }^{\circ} \mathrm{C}$ per decade were observed in Sudan as well as the northwestern and southern parts of Africa (Fig. 2e-f). For these increases of $\mathrm{T}_{\max }$ and $\mathrm{T}_{\min }, H_{0}$ of no trend was rejected $(\mathrm{p}<0.01$ or $|Z|$ $>2.57$ ) (Fig. 2a-b) in most locations. For the cooling trends in Madagascar (Fig. 2d-e), $H_{0}$ was not rejected
( $p>0.05$ or $|Z|<1.96$ ) (Fig. 2a-b). Except over some West African countries, the spatial distributions of $Z$ values for $\mathrm{T}_{\max }$ and $\mathrm{T}_{\min }$ were comparable (Fig. 2a-b).

Most parts of the continent were characterized by monthly PET increases at rates between 0.1 and $0.04 \mathrm{~mm} \mathrm{year}^{-1}$ (Fig. 2g). Large increases in PET at rates between 0.05 and $0.085 \mathrm{~mm}^{\text {year }}{ }^{-1}$ were observed along the western coastline of South Africa, northwestern areas like Tunisia, as well as some areas around Lake Victoria in the equatorial region 

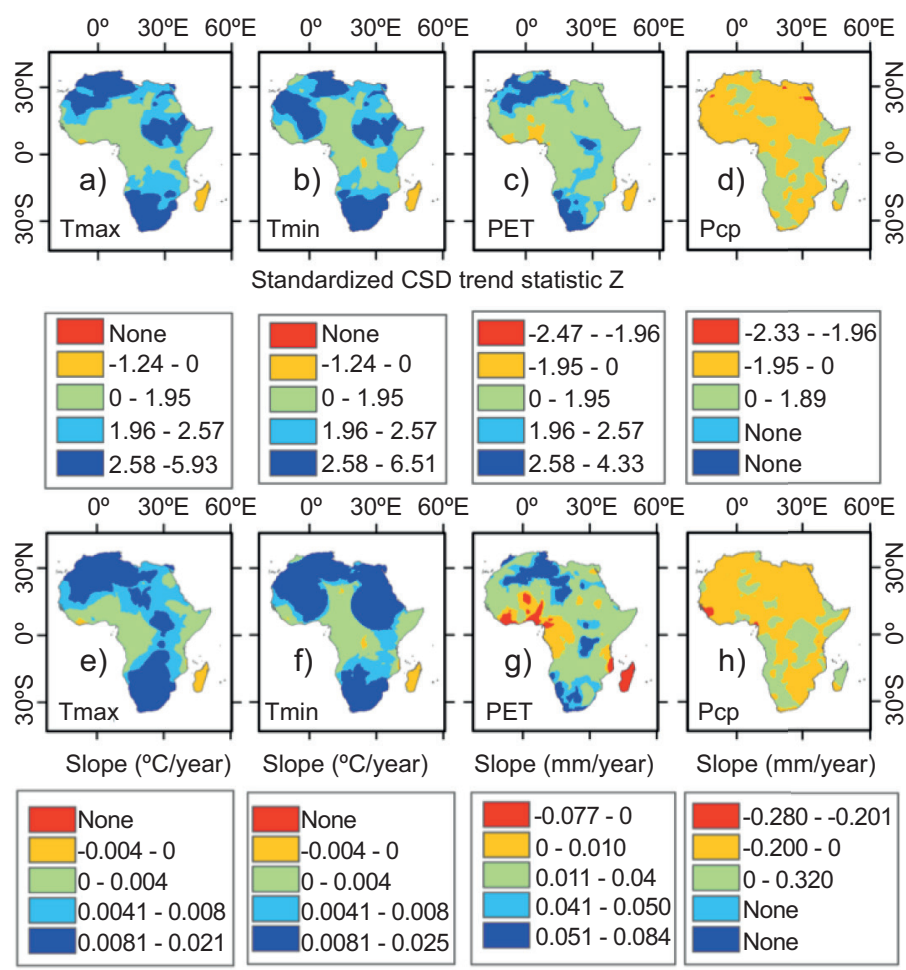

Fig. 2. Overall standardized trend statistic $Z$ for monthly (a) $T_{\max }$ $\left({ }^{\circ} \mathrm{C}\right)$, (b) $\mathrm{T}_{\min }\left({ }^{\circ} \mathrm{C}\right)$, (c) PET (mm), and (c) precipitation (Pcp, mm), and trend slopes for (e) $\mathrm{T}_{\max }$, (f) $\mathrm{T}_{\min }$, (g) PET, and (h) Pcp, averaged for all months from January to December.

of East Africa. For these increases, $H_{0}$ was rejected $(\mathrm{p}<0.01$ or $|Z|>2.57)$, as seen in Figure 2c. Along the coastline of the Gulf of Guinea, patches in some areas exhibited decreases in PET at rates as low as $-0.077 \mathrm{~mm}$ year $^{-1}$. However, for these decreases, $H_{0}$ was not rejected ( $\mathrm{p}>0.01$ or $|Z|<2.57$ ), as seen in Figure 2c.

Monthly Pcp across the continent was mainly characterized by drying at rates as low as $-0.20 \mathrm{~mm}$ year $^{-1}$ (Fig. 2h). Pcp decreases at rates between -0.3 and $-0.2 \mathrm{~mm}$ year $^{-1}$ were confined to the coastal areas of Guinea, Sierra Leone, and Gambia (Fig. 2 f). However, for the decreases, $H_{0}$ was not rejected ( $p>0.05$ or $|Z|<1.96$ ). Furthermore, Pcp increases were mainly of magnitudes between 0 and $0.1 \mathrm{~mm}$ year $^{-1}$. These increases were shown in the Great Lakes region, southwestern Africa and Madagascar (except its southernmost area) (Fig. 2h). However, for both Pcp increases and decreases, $H_{0}$ was mostly not rejected $(p>0.05)$ (Fig. 2d).

\subsubsection{Variability}

Figure 3 shows an overall average of the CSD variability $Z^{*}$ values obtained from data of various months (as can be seen from Figs. SM-15 to SM-18 of the supplementary material). The values 1.64, $1.96,2.58$, and 2.81 in the legend of Figure 3 are the thresholds for rejecting $H_{0}$ of natural randomness at $\alpha=0.10,0.05,0.01$, and 0.005 , respectively. Areas with low variability $\left(Z^{*}>2.81\right)$ in $T_{\max }\left(T_{\min }\right)$ were mainly between $10^{\circ} \mathrm{S}$ and $5^{\circ} \mathrm{N}\left(10^{\circ} \mathrm{N}\right.$ and $\left.10^{\circ} \mathrm{S}\right)$. High variability $\left(Z^{*}<1.63\right)$ in temperature was mainly found in Mozambique, Egypt, Mauritania, Western Sahara and around Lake Victoria (Fig. 3a-c). For Pcp, high variability was exhibited in South Africa, West Africa (especially along the Gulf of Guinea), East Africa, Madagascar, and areas with warm Mediterranean climate (Fig. 3d). Pcp variability was low $\left(Z^{*}>2.81\right)$ across the Sahara and Namib-Kalahari deserts. The significance of the variability statistic was found to vary from one region 


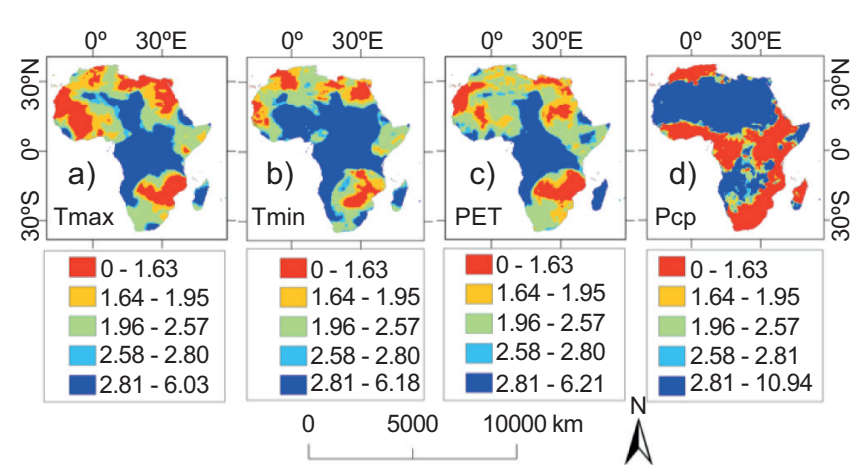

Fig. 3. Overall standardized variability statistic $Z *$ for (a) $T_{\max }$, (b) $T_{\min }$, (c) PET, and (d) Pcp based on data from January to December.

to another (Fig. 3a-d), which based on Figs. SM-15 to SM-18 of the supplementary material was found to be dependent on the month being considered.

\subsection{Covariability of subtrends from the selected cli- matic variables}

Results for the correlation between Pcp subtrends and those of $\mathrm{T}_{\max }, \mathrm{T}_{\min }$ and PET can be seen in Figures 4, 5 , and 6 , respectively, in which the values 0.25 and 0.31 are the thresholds for rejecting $H_{0}$ of no correlation at $\alpha=0.01$ and 0.001 , respectively. From May to September, a strong negative correlation between Pcp and $\mathrm{T}_{\max }$ (Fig. 4e-i), PET (Fig. 6e-i) and $\mathrm{T}_{\min }$ (Fig. 5e-i) was confined to the region between $4-21^{\circ} \mathrm{N}$. In southern Africa (generally south of $8^{\circ} \mathrm{S}$ ), a strong negative correlation between Pcp and $\mathrm{T}_{\max }$ was exhibited from January to March, May, October and December (Fig. 4a-c, e, j, 1). A strong negative correlation $(\mathrm{p}<0.001)$ between Pcp and $\mathrm{T}_{\max }$ or Pcp and PET was observed in the February, March, October, and November data, especially along the coast of the Mediterranean Sea. A strong positive correlation between Pcp and $\mathrm{T}_{\text {min }}$ of March (Fig. 5c) was observed in Mozambique, Zambia and Zimbabwe. However, in October (Fig. 5j) and August (Fig. 5h), the strong positive correlation between Pcp and $\mathrm{T}_{\min }$ was mainly confined to South Africa and the coastal areas along the Gulf of Guinea, respectively. A positive correlation between Pcp and $\mathrm{T}_{\max }$ (Fig. 4g-h) as well as Pcp and $\mathrm{T}_{\min }$ (Fig. 5g-h) during July and August was observed along the Gulf of Guinea, as well as the north of Morocco and Algeria. Over East Africa, a strong negative correlation $(p<0.001)$ between
Pcp and $\mathrm{T}_{\max }$ was osberved in April and November (Fig. 4d, k). In general, in January and February, areas with a strong correlation between Pcp and temperature or PET were far south of the equator. From March through April and May to June, in areas where $H_{0}$ was rejected $(\mathrm{p}<0.001)$ for a strong negative correlation the spatial coherence decreased consistently, but with increasing shifts northwards as far as $14^{\circ}$ N. Slightly past the middle of the year (July or August), a band of strong negative correlation was found in the Northern Hemisphere as far as $20^{\circ} \mathrm{N}$. The described shifts in areas with strong correlation between Pcp and temperature were more evident for $\mathrm{T}_{\max }$ than for $\mathrm{T}_{\min }$.

Generally, it is noticeable that in most areas, correlation coefficients between subtrends of Pcp and $\mathrm{T}_{\max }$ (Fig. 4a-1), Pcp and $\mathrm{T}_{\min }$ (Fig. 5a-1), and Pcp and PET (Fig. 6a-1) were mainly negative. Evidently, these negative correlations coefficients were mostly weak $(p>0.01)$ or fell in the range between 0 and -0.24 . However, areas with strong negative correlations were larger for $\mathrm{T}_{\max }$ and PET than that for $\mathrm{T}_{\min }$. On the other hand, areas with positive correlation were larger for $\mathrm{T}_{\min }$ than for $\mathrm{T}_{\max }$ and PET. Furthermore, by comparing maps for corresponding months, correlation coefficients between Pcp and $\mathrm{T}_{\max }$ (Fig. 4a-1) were more comparable spatially with the results for PET (Fig. 6a-1) than for $\mathrm{T}_{\min }$ (Fig. 5a-1).

Figure 7 shows the results of wavelet coherence analysis. The reliable data within the "cone of influence" away from the edge effects are indicated by the colored region. Significantly coherent areas are enclosed in bold black lines derived with Monte Carlo randomizations. The strength of coherence between 


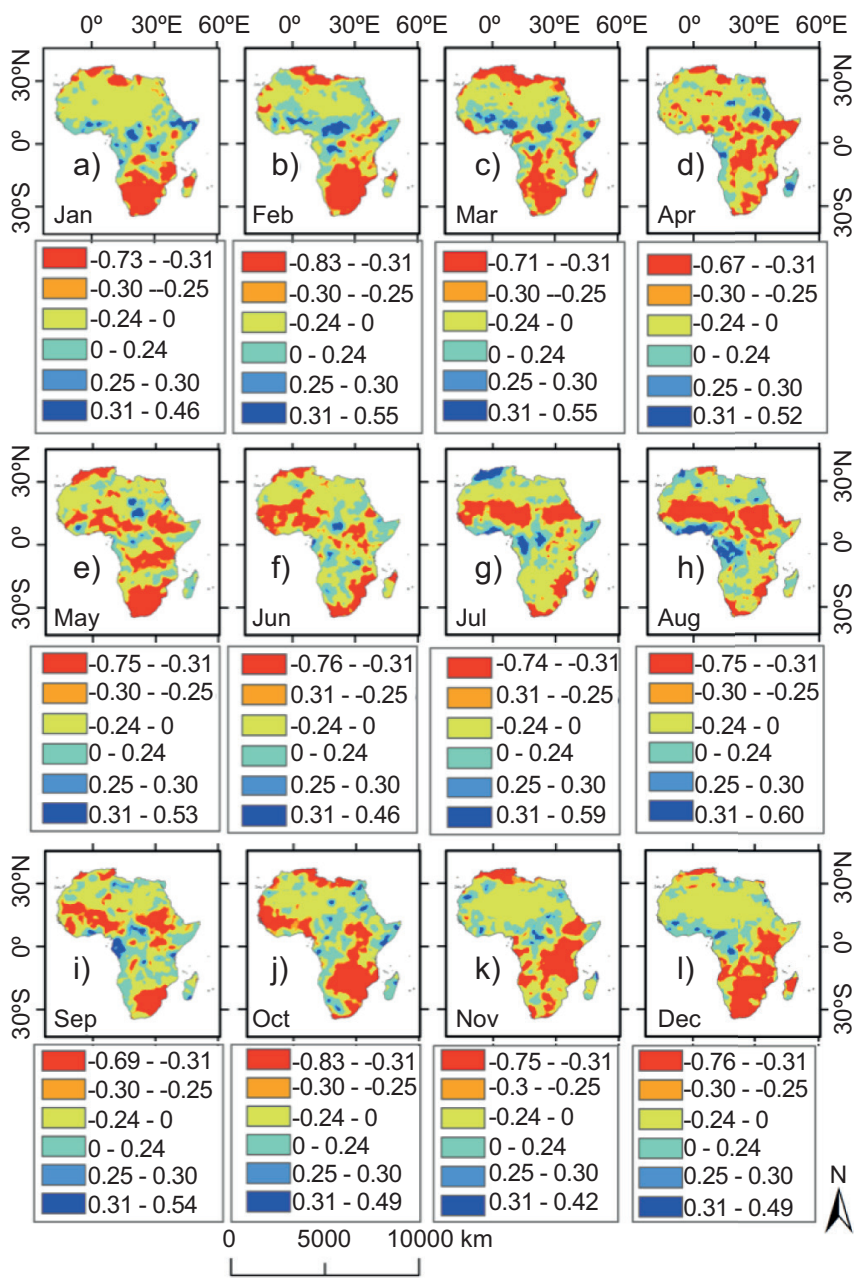

Fig. 4. Correlation coefficients between Pcp and $\mathrm{T}_{\max }$ for (a) January to (1) December.

the time series at each period through time can be seen in terms of colors. The color at the bottom (top) of the legend bar indicates low (high) coherency.

The strength of the Pcp with $\mathrm{T}_{\max }, \mathrm{T}_{\min }$ or PET covariation was inconsistent through time (Fig. 7a-c). The strongest coherence between Pcp and PET occurred at multiple scales (2-5 years, Fig. 7a). Coherence between Pcp and PET was strong over the periods 1905-1925 and 1985-2005 (Fig. 7a). Pcp cycled in anti-phase with PET from 1985 to 2005. The strongest coherence between Pcp and $\mathrm{T}_{\min }\left(\right.$ or $\mathrm{T}_{\max }$ ) occurred at multiple scales (6-8 years, Fig. 7b-c). Strong coherence of Pcp with $\mathrm{T}_{\max }$ and $\mathrm{T}_{\min }$ was observed over the periods 1901-1935
(Fig. 7b) and 1901-1925 (Fig. 7c), respectively. Pcp cycled in anti-phase with $T_{\max }$ from 1901 to 1935 . Coherence between PET and temperature remained strong at multiple scales (from 1 to about 30 years) over the entire data period (1901-2015). Arrows in this figure show phase relationships between the variables within the areas of strong coherence. In Figure $7 \mathrm{~d}-\mathrm{f}$, the arrows point to the right meaning that PET and $\mathrm{T}_{\max }$, PET and $\mathrm{T}_{\min }$, as well as $\mathrm{T}_{\min }$ and $\mathrm{T}_{\max }$ are in phase. This indicates that PET has a strong positive influence from temperature. Some arrows in Figure 7a-c point to the left indicating that Pcp and PET or Pcp and temperature are in anti-phase. From 1901 to 1935, Pcp cycled downwards with $T_{\min }$ at multiple 


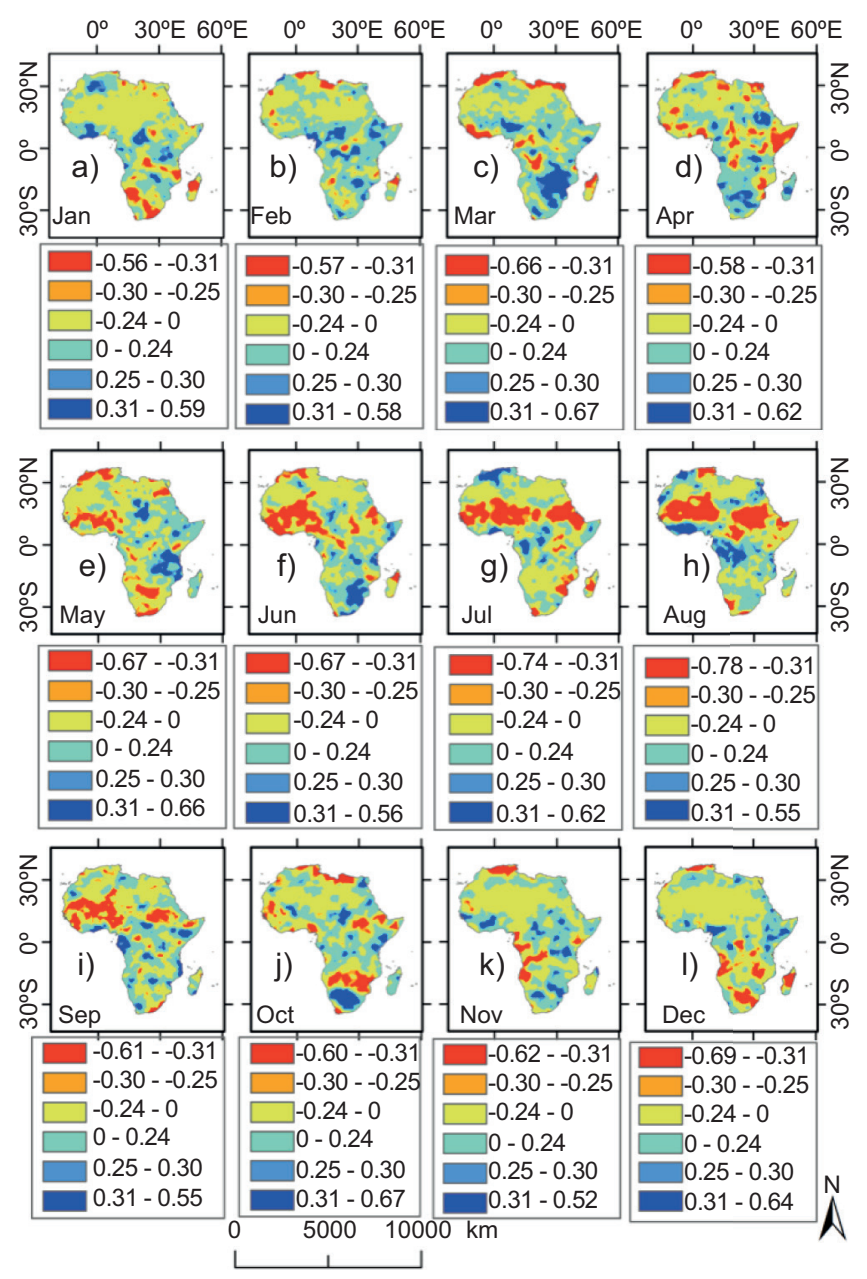

Fig. 5. Correlation coefficients between Pcp and $\mathrm{T}_{\min }$ for (a) January to (l) December.

scales (15-16 years), which means that $T_{\text {min }}$ led Pcp by $\pi \times 2^{-1}$. However, Pcp cycled upwards with $T_{\min }$ at multiple scales (1.4 years, Fig. $7 \mathrm{c})$. This means that $\mathrm{T}_{\min }$ led Pcp by $\pi \times 2^{-1}$.

\section{Discussion}

\subsection{Trends and variabilty results}

The results of this study are consistent with the findings of several previous studies, especially regarding trends. The confidence level in the evidence of warming over land regions across the African continent is high (Niang et al., 2014). Throughout the 20th century, the African continent warmed at a rate of $0.58{ }^{\circ} \mathrm{C}$ per decade (Hulme et al., 2001).
A significant rise in African temperature occurred between 1979 and 2010 (Collins, 2011).

Regarding the equatorial region (specifically around Lake Victoria in East Africa), Nyeko-Ogiramoi et al. (2013) and Kizza et al. (2009) found mainly positive trends in the seasonal rainfall. Furthermore, $\mathrm{T}_{\min }$ and $\mathrm{T}_{\max }$ over the period 1970-2010 generally exhibited trends to rising temperatures (Nyeko-Ogiramoi et al., 2013). Significant warming and drying were confirmed in the western equatorial Africa (Bush et al., 2020). Pcp and $\mathrm{T}_{\text {min }}$ data from the weather of Lopé in Gabon, observed over the period 1984-2018, revealed that warming occurred at a rate of $+0.25^{\circ} \mathrm{C}$ per decade and this was accompanied by a drying rate of $-75 \mathrm{~mm}$ per decade (Bush et al., 2020). 

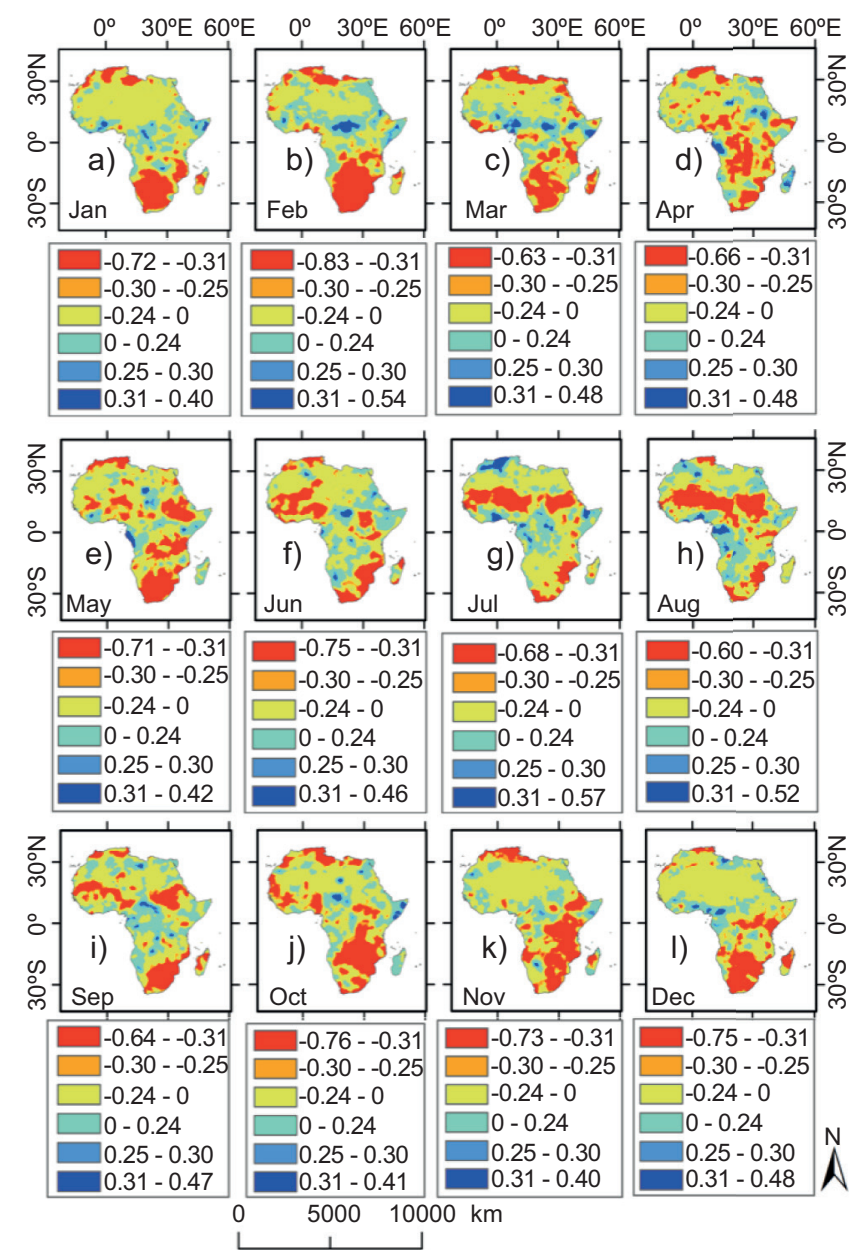

Fig. 6. Correlation coefficients between Pcp and PET for (a) January to (1) December.

The West African Sahel was characterized by a general warming trend from 1960 to 2010 (Ly et al., 2013). Even the data from various stations across the Volta basin of West Africa between 1960 and 2002 exhibited significant warming trends (Neumann et al., 2007). Pcp exhibited a decrease, especially along the Gulf of Guinea and the Congo River basin (Onyutha, 2018a).

For Egypt and Sudan, this study showed that: $(i)$ $\mathrm{T}_{\max }$ and $\mathrm{T}_{\min }$ exhibited increasing trends at rates from 0.041 to $0.25^{\circ} \mathrm{C}$ per decade, (ii) Pcp decreased at rates between -25 and $0 \mathrm{~mm}$ per decade, and (iii) PET yielded positive trends with magnitudes on the range from 1.32 to $4.8 \mathrm{~mm}$ per decade. El Kenawy et al. (2019) found that $T_{\max }$ in Egypt exhibited a stronger warming than $\mathrm{T}_{\min }$ in the period 1983-2015.
Conversely, Nashwan et al. (2019) showed that $\mathrm{T}_{\min }$ increased much faster $\left(0.08-0.29^{\circ} \mathrm{C}\right.$ per decade $)$ than $\mathrm{T}_{\max }\left(0.07-0.24^{\circ} \mathrm{C}\right.$ per decade) across Egypt. Rainfall in Egypt was also characterized by decreasing trends (Gado et al., 2019).

For South Africa, Karl et al. (1993) also reported positive trends for both $\mathrm{T}_{\max }$ and $\mathrm{T}_{\min }$ over the period 1951-1991. According to MacKellar et al. (2014), $\mathrm{T}_{\max }$ in South Africa from 1960 to 2010 exhibited a positive trend. However, decreasing trends in both $\mathrm{T}_{\max }$ and $\mathrm{T}_{\min }$ between 1940 and 1989 were reported in South Africa by Muhlenbrunch-Tegen (1992). Furthermore, Hulme et al. (2001) showed a cooling tendency over the coastal areas of South Africa considering the period 1901-1995. In this study, cooling was not evident in the coastal areas of 

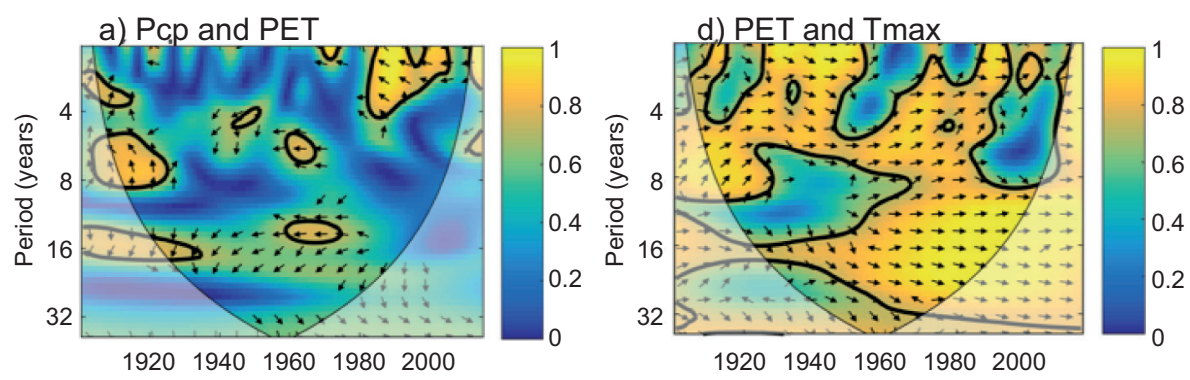

b) Pcp and Tmax
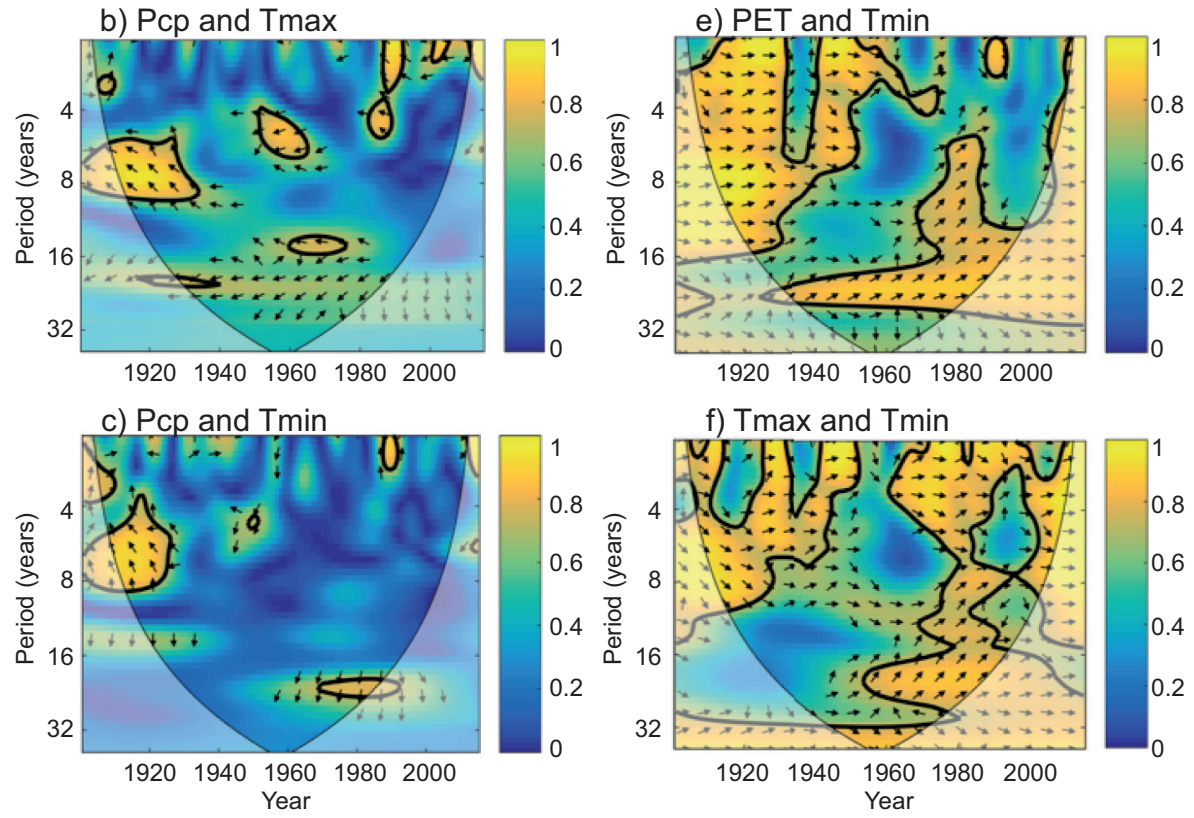

Fig. 7. Wavelet coherence plots for (a) Pcp and PET, (b) Pcp and $T_{\max }$, (c) Pcp and $\mathrm{T}_{\min }$, (d) PET and $\mathrm{T}_{\max }$, (e) PET and $\mathrm{T}_{\min }$, and (f) $\mathrm{T}_{\max }$ and $\mathrm{T}_{\min }$.

South Africa, in contrast with Madagascar (near the eastern coastal area of South Africa). Some possible discrepancies of the results in this paper with those of previous studies are due to differences in the data periods used, for instance, 1901-1995 (Hulme et al., 2001), 1940-1989 (Muhlenbrunch-Tegen, 1992), and 1901-2015 in the present study. Trend results depend on the period considered for analyses (Onyutha et al., 2016). Another reason is the effect of seasonality, which was explicitly considered in this study but ignored by previous researchers.

\subsection{Covariation of Pcp with $T_{\max }, T_{\min }$, and PET} The general negative correlation coefficients between Pcp and temperature subtrends indicate that as temperature increases, total Pcp decreases and vice versa; however, as temperature increases, PET also increases.
In other words, a direct relationship exists between temperature and PET. High temperature implies an increase in the amount of energy for the conversion of liquid water to water vapor. Also, an increase in temperature widens plant leaves' stomata, allowing more water vapor to escape than under conditions with reduced temperature. Water demands to meet evaporation and transpiration are supplied by Pcp. Thus, as Pcp increases, PET is also expected to increase. However, PET rates are controlled by several factors besides Pcp, such as: (i) humidity (evaporation rates decrease when an area is too humid), (ii) wind speed (evaporation rates increase when air is moving or humidity is being cleared by the wind), (iii) soil moisture (in dry soil, nature permits infiltration and sufficient water uptake by plants or vegetation prior to evaporation), and (iv) vegetation 
or plant type (while trees and crops are generous in losing water, some plants like cacti naturally prefer holding onto their water instead of easily giving it up for transpiration). Importantly, dry conditions mean more sunshine and less evaporative cooling, especially over land.

At some locations where $H_{0}$ was rejected $(\mathrm{p}<$ $0.001)$, multi-decadal temporal changes in temperature could be inferred from the variations in Pcp. However, considering the long-term, it is evident that the temperature-Pcp covariation depends on the period used for analysis, which also applies to the relationship between PET and Pcp. For instance, as shown in Figure SM-2 of the supplementary material, $\mathrm{T}_{\max }, \mathrm{PET}$ and $\mathrm{T}_{\min }$ generally exhibited negative trend slopes in the period 1941-1978; however, positive trends were observed in the periods 19011940 and 1979-2015. On the other hand, Pcp was on average characterized by positive and negative trends over the periods 1901-1960 and 1961-1990, respectively. Thus, trend slopes in both temperature and Pcp, as well as PET, were positive from 1901 to 1940; however, from 1979 to 1990 , temperature and PET increased while Pcp declined over time. In fact, a rise in temperature increases the atmospheric evaporative demand and eventually Pcp is expected to increase. This is because high temperatures enhance the increase of warm moisture, thereby producing convection. Despite the general warming across Africa, some regions were characterized by drying trends, while in other areas Pcp increased. Besides, the warming trends across various regions of the continent are due to different influences. For instance, tropical North Africa is very warm due to a number of reasons, including: $(i)$ because of its low latitude it receives a large amount of incoming solar radiation, (ii) its elevation is mostly less than 1000 masl, and (iii) advection of cool oceanic air from the tropical North Africa towards the interior (Sahelian and Sudanian belts) is inhibited by the general easterly trade winds coupled with the size of the African continent north of the equator (Moron et al., 2016).

Pcp totals differ across the various regions of the continent, which can be thought of in terms of the influence from the shifts in ocean currents and wind patterns. For instance, heat motion is majorly influenced by ocean dynamics while the cycles of the El Niño Southern Oscillation (ENSO) responsible for the wet and dry conditions in several areas follow atmosphere-ocean interactions. According to Trenberth et al. (2010), during the La Niña phase there is a major uptake of heat by the ocean. The absorbed heat is stored in the tropical western Pacific. The ocean cools as the atmosphere responds with typical El Niño weather patterns forced from the region (Trenberth et al., 2010), which tends to be a typical source of influence on Pcp across various areas of the world.

The monthly spatial transition in the temperature-Pcp correlation (described in the results section) is typical of the latitudinal migration of the Inter-Tropical Convergence Zone (ITCZ). However, the analogy with the ITCZ migration was clearer for $\mathrm{T}_{\max }$ than for $\mathrm{T}_{\min }$. This is because the sensitivity of temperature extremes to local influences is higher for $\mathrm{T}_{\min }$ than for $\mathrm{T}_{\max }$. Pcp patterns and distributions across Africa dominantly rely on the migration of the ITCZ. A band of Pcp moves with the ITCZ as it migrates from its southernmost location (in January) to the northern extreme (in July). The lack of a high spatial coherence in the temperature-Pcp correlation over the equatorial region is due to the joint impacts of the Great Lakes and the high mountains on Pcp and temperature. The joint impact of the lakes and upslope breezes has considerable influence on convection, and subsequently on temperature. It is also worth noting that in cool highland areas, Pcp tends to be associated with above normal temperature; however, in the lowlands and hot environments, as well as the onset of the rainy season, Pcp occurrence is associated with below normal temperature (Camberlin, 2017).

\subsection{General implications of the warming and drying trends}

The warming trends found in most parts of the continent have wide-ranging implications. A positive trend in temperature means an increase in the intensity of heat waves, thereby leading to many cases of illnesses or even deaths in several regions of the continent, given the high vulnerability of local populations. Continued increases in temperature present high possibilities of severe and/or persistent dry conditions. This is because PET depends on $\mathrm{T}_{\max }$ and $\mathrm{T}_{\text {min }}$. Thus, positive trends in $T_{\max }$ and $\mathrm{T}_{\min }$ imply an increase in total PET, which in turn leads to a decline in soil moisture (especially if Pcp is insufficient) and severe 
lack of water for crops. By inducing water and heat stress, dry conditions (due to soaring temperatures, high evaporation, and subsequent decline in soil moiture) negatively affect crop production. Increasing temperature and declining Pcp totals lead to crop failure, thereby exacerbating food insecurity, which is already a formidable challenge to the subsistence of poor populations across Africa (especially in the sub-Saharan region). The dry and wet conditions in several locations across the continents tend to be characterized by late onset of Pcp, reduced length of the wet season (or longer than normal dry conditions), and soaring temperatures. Such changes tend to greatly affect dryland ecosystems, which are sensitive to changes in temperature and Pcp.

To meet the requirements of predictive adaptation in areas or regions with significant positive trends in temperature $\left(\mathrm{T}_{\max }\right.$ and $\left.\mathrm{T}_{\min }\right)$ and PET, smallholder farming should be based on drought-tolerant crop varieties. Good farming practices (for instance, using mulching to improve soil moisture and fertility) should be encouraged in smallholder farming; however, tackling food insecurity amid uncertain climatic conditions, especially in sub-Saharan Africa, requires an interplay of science and policy (Onyutha, 2019). For instance, policy makers should ensure quick variety testing, as well a fast approval of the new crop varieties being developed. This should be done while addressing factors that hamper the adoption of scientifically improved crop varieties by farmers. Global collaboration regarding scientific research that supports agriculture is crucial to tackle food insecurity in Africa. Further measures should be taken, including increasing farmer's access to markets, promoting non-farming activities, minimizing the differences in priorities across various subsectors of farming in sub-Saharan Africa, and addressing disparity in initiatives of regional and national dynamics (Onyutha, 2018c).

Deviations of Pcp and temperature from their normal conditions increase the risk of conflicts (Hsiang and Meng, 2014; Hendrix and Salehyan, 2012). The way in which local populations respond to the impacts of increased warming and drying may lead to various other repercussions. Migration as an adaptive response to local environmental pressures (Tacoli, 2009; Warner, 2010) leads to health risks (Serdeczny et al., 2016) and tensions between ethnic groups, political and legal restrictions, and competition for (and limitations on) access to land (Tacoli, 2009). According to Burke et al. (2009), the likelihood of civil war is higher in hotter years. In other words, warming increases the risks of civil wars in Africa (Burke et al., 2009). Conversely, Aldhous (2010) remarked that civil war in Africa has no link to global warming. Thus, climate should not be blamed for African civil wars (Buhaug, 2010). Nonetheless, the exacerbation of conflicts by the influence of drying and warming trends cannot be disregarded depending on a number of factors considered for analysis, such as: $(i)$ which indicators of conflicts are used, (ii) which region is considered, and (iii) which period (or time frame) is chosen. Besides, drying and warming trends may lead to conflicts indirectly, thus the origins will be difficult to unearth. This could be the reason for a lack of evidence on the relationship between violent conflicts and climate change (Gleditsch, 2012). It remains a fact that local populations will always tend to adapt to prolonged local environmental stresses. For instance, due to prolonged conditions of extreme heat and severe drought, pastoral communities adapt by moving from one place to another. This migration may be further and wider than in short-lived conditions of heat and water stress. Competition for resources (such as water, land, and pasture) by residents and immigrants may heighten conflicts. In order to alleviate poverty in local communities striving to adapt to the impacts of warming and drying trends on livelihood, policies should be established to promote non-farming incomes and creating jobs and employment opportunities for the rural population.

Increasing temperature and PET, alongside declining Pcp totals, imply a decrease in rainfall-runoff volumes. Thus, if warming and drying trends continue, the future water supply from rivers will be characterized by seasonal shortages. There are several applications which depend on volumes of water in the rivers, some of which include irrigation, reservoir operations, hydropower scheduling, and flow control for ecological purposes. Increasing water demand for irrigation and hydropower production is triggered by pressure arising from high population growth, especially in the sub-Saharan region. It is known that groundwater is the key source of safe drinking water in that region (MacDonald et al., 2009). However, 
drying and warming trends also pose a serious risk for the reduction of volumes of water to recharge groundwater. In adapting to the impacts of warming and drying trends there should be a sustainable use of water resources.

\subsection{Implications of changes in PET, temperature and Pcp for arid environments}

The way in which changes in temperature, Pcp and other climatic factors affect regional evapotranspiration and net primary productivity in various arid environments of the world has been widely studied (McVicar et al., 2011; Bai et al., 2014; Onyutha, 2016c). Variations in Pcp were found to significantly $(p<0.05)$ explain changes in PET across the River Nile riparian countries (Onyutha, 2016c). In another relevant study for an arid environment (though in the northwest of China), Bai et al. (2014) quantified the contributions of agricultural oasis expansion, management practices and climate change to net primary production and evapotranspiration. Furthermore, McVicar et al. (2011) assessed the impact of trends in the observed terrestrial near-surface wind speeds for evaporation.

The results of this study are vital for an insight into the ecohydrology of water-limited ecosystems. In arid regions, evapotranspiration comprises a significant water budget component (Glenn et al., 2010). Generally, water (followed by nitrogen) is the most vital limiting variable for plant growth in arid conditions (Smith et al., 1997). Therefore, in arid regions, the plant community composition, function, and structure tend to be greatly influenced by possible controls on water movement (Loik et al., 2004). Eventually, the amount of water that becomes available for root water uptake is also affected (Young et al., 2009). On one hand, it may be claimed that water can be efficiently used by vegetation in dryland ecosystems (Huxman et al., 2004); on the other hand, water use efficiency might vary based on the composition of plant species over the landscape (Huxman et al., 2005). As opposed to arid regions, semi-arid systems tend to be mainly driven by Pcp. Long-term changes in climatic variables such as PET and Pcp may be linked to the impacts of human factors. For instance, the rapid expansion of cropland and intensive agricultural management practices can greatly affect regional carbon and water budgets (Bai et al.,
2014). Other relevant human factors which lead to changes in climatic variables include over-grazing, massive deforestation, transition in land-use or cover, and urbanization. An insight into the present and potential future vegetation and water availability in arid environments may be obtained by understanding how the ecosystem evapotranspiration is regulated (Wilske et al., 2009).

Positive trends in PET (and temperature) imply an increase in the demand of crop water requirements. The cropping system in sub-Saharan Africa is almost entirely rainfed. However, addressing the water shortage issue to enhance crop yield implies an increase in irrigation requirements, but in irrigated and desert areas water shortage in turn indirectly affects soil salinity of the root zone (Abderrahman et al., 1991). Especially under elevated water requirements, plants tend to consume some water from the leaching fraction thereby increasing soil salinity and causing a subsequent yield loss (Abderrahman et al., 1991).

Results of long-term trends and decadal changes in evapotranspiration (and Pcp) indicate whether a region will be wetter or drier than its past climatic conditions. The findings of this study can be useful for a careful planning of water resources management, for instance, to determine how much water can be used to support environmental needs after safely being allocated for human use (Bunting et al., 2014). Long-term increase of PET and a negative trend in Pcp imply that the PET to Pcp ratio increases over time. The evapotranspiration to Pcp ratio is important in arid and semiarid ecosystems (Glenn et al., 2014) because water that is not lost through evapotranspiration can produce runoff and groundwater recharge, thereby influencing erosion, aquifer properties and regional stream flows (Milly, 1994). Furthermore, changes in ecohydrological variables such as the PET to Pcp ratio can be taken as indicators of the transition in vegetation communities, especially across drylands (Heilman et al., 2014). For instance, the evapotranspiration to Pcp ratio varies across woodland, grassland and shrubland ecosystems.

Before 2000, the Sahara Desert was shown to be changing in size by both expanding and contracting at some points over time (Tucker et al., 1991; Tucker and Nicholson, 1999). Recently, an amplified warming trend has also been found in the Sahara Desert (Cook and Vizy, 2015; Zhou, 2016). The results of this study, which indicate an increasing trend in 
long-term (1901-2015) temperature and PET, accompanied by Pcp decrease across North Africa, point towards an expansion of the Sahara Desert, whose variation in size (especially the increase) has major implications in terms of the influence of Saharan dust on sea surface temperatures as well as the occurrences of Atlantic hurricanes (see Evan et al., 2016). If the Sahara Desert continues to expand it will have significant socioeconomic and environmental impacts. For instance, the affected population will have to live under abnormal water-stressed conditions. Furthermore, many people will be displaced by harsh environmental conditions. The question should be: What steps need to be taken? It is worth noting that apart from low rainfall and dry conditions, other factors which enhance desertification and subsequent degradation of soils include dust transport and wind erosion (McLeod, 1976). Therefore, some of the critical steps to be followed in line with desertification include reinstating degraded soil ecosystems and scaling-up land use and/or land management practices which are sustainable.

\section{Conclusions}

In this study, trends and variability were analyzed through monthly long-term (1901-2015) $\mathrm{T}_{\max }, \mathrm{T}_{\min }$, PET, and Pcp. Each climatic variable was obtained in gridded form with $0.5^{\circ} \times 0.5^{\circ}$ spatial resolution over the entire African continent. The variation of subtrends in Pcp and $\mathrm{T}_{\max }, \mathrm{T}_{\text {min }}$, and PET was compared through correlation analysis.

The African continent was characterized by warming over the periods 1901-1940 and 1979-2015 (end of data). However, the continent experienced some cooling from 1941 to the mid 1970s. The warming of the continent from 1979 to 2015 was stronger than over the period 1901-1940. The increasing/drying rates of $\mathrm{T}_{\max }, \mathrm{T}_{\min }$, and PET annual trends for the period 1979-2015, averaged over the entire continent, were $0.18{ }^{\circ} \mathrm{C}, 0.22^{\circ} \mathrm{C}$, and $3.5 \mathrm{~mm}$, respectively. The 1961-1990 annual Pcp, averaged over the whole continent, showed that Africa experienced drying at a rate of about $-28 \mathrm{~mm}$ per decade. When considering the period 1961-2015, Pcp decreased at a rate of about $-8 \mathrm{~mm}$ per decade. Areas around Lake Victoria in East Africa and along the western coastline south of the equator were characterized by wetting at rates as high as $36 \mathrm{~mm}$ per decade. Sudan, as well as southern and northern Africa, experienced significant ( $p$ $<0.01)$ warming trends. Positive PET trends were significant $(p<0.01)$ in the warm Mediterranean climate and the western part of South Africa. Some regions were characterized by drying trends while in other areas Pcp increased.

Temperature and PET variability was low in the equatorial climate. Areas with high variability in temperature included Mozambique, Egypt, Mauritania, the Western Sahara, and the Lake Victoria region. Pcp variability was high across the continent. However, Sahara and Namib-Kalahari deserts were characterized by low Pcp variability.

The strength of the Pcp covariation with $\mathrm{T}_{\max }, \mathrm{T}_{\text {min }}$ or PET was inconsistent through time. The strongest coherence between Pcp and PET occurred at multiple scales (2-5 years). Pcp cycled in anti-phase with PET from 1985 to 2005 . The strongest coherence between Pcp and $\mathrm{T}_{\min }$ (or $\mathrm{T}_{\max }$ ) existed at multiple scales (6-8 years). A strong coherence of Pcp with $\mathrm{T}_{\max }$ and $\mathrm{T}_{\min }$ was observed over the periods 1901-1935 and 19011925 , respectively.

A negative (and weak) correlation was mainly found between Pcp and temperature and/or PET. Thus, as temperature increases, total Pcp tends to decrease, although the temperature-Pcp covariation and the relationships between PET and Pcp depend on the analysis period. The monthly spatial variation in locations with strong correlation between temperature and Pcp was found to be analogous to the latitudinal migration of the ITCZ; however, there was an overall lack of high spatial coherence in the correlation between Pcp and temperature in the equatorial region due to the joint impact of the breezes from the Great Lakes and the high mountains on convection, and subsequently on temperature.

Increasing temperature can amplify the intensity of heat waves, which produces many cases of illnesses or even deaths in affected areas. Increasing PET and decreasing Pcp totals can lead to a decline in soil moisture, thereby increasing crop water stress. Smallholder farming in affected areas should be based on drought-tolerant crop varieties and good farming practices such as the use of mulching to improve soil moisture and fertility.

Deviations of Pcp and temperature from their normal conditions can lead to migration of some 
communities (for instance the nomads) as an adaptation response to local environmental pressures. This can provoke conflicts between residents and immigrants in a particular location due to competition for resources such as agricultural land and pasture or water for livestock. It is important to remark that the way in which drying and warming trends lead to conflicts may be indirect, thus difficult to unearth. To avoid such conflicts, authorities must be committed to poverty alleviation through actionable policies that promote non-farming income and the creation of employment opportunities for the rural population.

If warming and drying trends continue, the future variability of water supply from rivers will be characterized by seasonal shortages, and volumes of water to recharge groundwater will decrease. Hydrological applications that rely on such volumes of water will be affected, so it is vital to plan a predictive and sustainable use of water resources to cope with possible impacts of warming and drying trends in the affected areas. The possibility of a Sahara Desert expansion implies significant socioeconomic and environmental impacts, such as abnormal water stress. Some of the adaptive measures for the affected areas include reinstating degraded soil ecosystems and scaling-up sustainable land use and/or land management practices.

This study shows the covariability of Pcp with temperature or PET. Thus, the drivers of variability of PET and temperature can be inferred from those of Pcp. Analyses results for the covariation of several climate indices with Pcp across the entire African continent can be found in a number of studies such as Onyutha (2018a) and Nicholson and Selato (2000).

\section{Supplementary material}

Auxiliary information to aid the interpretation of this article is available at: https://www.revistascca. unam.mx/atm/SupplementaryMaterial/52788-Onyutha-SupMat.pdf

\section{Acknowledgments}

Data series used in this study were obtained from the Climatic Research Unit Time-Series v. 4.0 (CRU TS4.0).

\section{References}

Abderrahman WA, Bader TA, Kahn AU, Ajward MH. 1991. Weather modification impact on reference evapotranspiration, soil salinity and desertification in arid regions: A case study. Journal of Arid Environments 20: 277-286. https://doi.org/10.1016/S01401963(18)30689-X

Ahokpossi Y. 2019. Analysis of the rainfall variability and change in the Republic of Benin (West Africa). Hydrological Sciences Journal 63: 2097-2123. https:// doi.org/10.1080/02626667.2018.1554286

Aldhous P. 2010. Civil war in Africa has no link to climate change. New Scientist 207: 11-14. https://doi. org/10.1016/S0262-4079(10)62176-8

Allen RG, Smith M, Pereira LS, Perrier A. 1994. An update for the calculation of reference evapotranspiration. ICID Bulletin 43: 35-92.

Armal S, Devineni N, Khanbilvardi R. (2018). Trends in extreme rainfall frequency in the contiguous United States: Attribution to climate change and climate variability modes. Journal of Climate 31: 369-385. https:// doi.org/10.1175/JCLI-D-17-0106.1

Bai J, Chen X, Li L, Luo G, Yu Q. 2014. Quantifying the contributions of agricultural oasis expansion, management practices and climate change to net primary production and evapotranspiration in croplands in arid northwest China. Journal of Arid Environments 100-101: 31-41. https://doi.org/10.1016/j. jaridenv.2013.10.004

Bates BC, Kundzewicz ZW, Wu S, Palutikof JP. 2008. Climate change and water. Technical paper. Intergovernmental Panel on Climate Change, Geneva. Available at: https://www.ipcc.ch/site/assets/uploads/2018/03/ climate-change-water-en.pdf (accessed: September 24, 2019).

Beltrando G, Camberlin P. 1993. Interannual variability of rainfall in the Eastern Horn of Africa and indicators of atmospheric circulation. International Journal of Climatology 13: 533-546. https://doi.org/10.1002/joc.3370130505

Buhaug H. 2010 Climate not to blame for African civil wars. Proceedings of the National Academy of Sciences 107: 16477-16482. https://doi.org/10.1073/ pnas. 1005739107

Bunting DP, Kurc SA, Glenn EP, Nagler PL, Scott RL. 2014. Insights for empirically modeling evapotranspiration influenced by riparian and upland vegetation in semiarid regions. Journal of Arid Environment 111:4252. https://doi.org/10.1016/j.jaridenv.2014.06.007 
Burke B, Miguel E, Satyanath S, Dykema JA, Lobell DB. 2009. Warming increases the risk of civil war in Africa. Proceedings of the National Academy of Sciences 106:20670-20674. https://doi.org/10.1073/ pnas.0907998106

Bush ER, Jeffery K, Bunnefeld N, Tutin C, Musgrave R, Moussavou G, Mihindou V, Malhi Y, Lehmann D, Edzang Ndong J, Makaga L, Abernethy K. 2020. Rare ground data confirm significant warming and drying in western equatorial Africa. PeerJ 8:e8732. https://doi. org/10.7717/peerj.8732

Camberlin P. 2017. Temperature trends and variability in the Greater Horn of Africa: interactions with precipitation. Climate Dynamics 48(1-2):477-498. https://doi. org/10.1007/s00382-016-3088-5

Collins JM. 2011. Temperature variability over Africa. Journal of Climate 24(14):3649-3666. https://doi. org/10.1175/2011JCLI3753.1

Cook KH, Vizy EK. 2015. Detection and analysis of an amplified warming of the Sahara Desert. Journal of Climate 28:6560-6580. https://doi.org/10.1175/JCLI-D-14-00230.1

El Kenawy AM, Lopez-Moreno JI, McCabe MF, Robaa SM, Domínguez-Castro F, Peña-Gallardo M, Trigo RM, Hereher ME, Al-Awadhi T, Vicente-Serrano SM. 2019. Daily temperature extremes over Egypt: Spatial patterns, temporal trends, and driving forces. Atmospheric Research 226:219-239. https://doi. org/10.1016/j.atmosres.2019.04.030

Evan AT, Flamant C, Gaetani M, Guichard F. 2016. The past, present and future of African dust. Nature 531:493-495. https://doi.org/10.1038/nature17149

Gado TA, El-Hagrsy RM, Rashwan IMH. 2019. Spatial and temporal rainfall changes in Egypt. Environmental Science and Pollution Research 26:28228-28242. https://doi.org/10.1007/s11356-019-06039-4

Gleditsch P. 2012. Whither the weather? Climate change and conflict. Journal of Peace Research 49:3-9. https:// doi.org/10.1177/0022343311431288

Glenn EP, Nagler PL, Huete AR. 2010. Vegetation index methods for estimating evapotranspiration by remote sensing. Surveys in Geophysics 6:531-555. https://doi. org/10.1007/s10712-010-9102-2

Glenn EP, Scott RL, Nguyen U, Nagler PL. 2014. Wide-area ratios of evapotranspiration to precipitation in monsoon-dependent semiarid vegetation communities. Journal of Arid Environments 117: 84-95. https://doi. org/10.1016/j.jaridenv.2015.02.010
Grist JP, Nicholson SE. 2001. A study of the dynamic forces influencing rainfall variability in the West African Sahel. Journal of Climate 14: 1337-1359. https://doi.org/10.1175/1520-0442(2001)014<1337: ASOTDF $>2.0 . \mathrm{CO} ; 2$

Harris I, Jones PD, Osborn TJ, Lister DH. 2014. Updated high resolution grids of monthly climatic observations-the CRU TS3.10 dataset. International Journal of Climatology 34: 623-642. https://doi.org/10.1002/joc.3711

Heilman JL, Litvak ME, McInnes KJ, Kjelgaard JF, Kamps RH, Schwiining S. 2014. Water-storage capacity controls energy partitioning and water use in karst ecosystems on the Edwards Plateau, Texas. Ecohydrology 7 : 127-138. https://doi.org/10.1002/eco.1327

Hendrix CS, Salehyan I. 2012. Climate change, rainfall, and social conflict in Africa. Journal of Peace Research 49: 35-50. https://doi.org/10.1177/0022343311426165

Hsiang SM, Meng KC. 2014. Reconciling disagreement over climate conflict results in Africa. Proceedings of the National Academy of Sciences 111: 2100-2103. https://doi.org/10.1073/pnas.1316006111

Hulme M, Doherty R, Ngara T, New M, Lister D. 2001. African climate change: 1900-2100. Climate Research 17: 145-168. https://doi.org/10.3354/cr017145

Huxman T, Smith M, Fay P, Knapp A, Shaw M, Loik M, Smith S, Tissue D, Zak J, Weltzin J, Pockman W, Sala O, Haddad B, Harte J, Koch G, Schwinning S, Small E, Williams D. 2004. Convergence across biomes to a common rain-use efficiency. Nature 429: 651-654. https://doi.org/10.1038/nature02597

Huxman T, Wilcox B, Breshears D, Scott R, Snyder K, Small E, Hultine K, Pockman W, Jackson R. 2005. Ecohydrological implications of woody plant encroachment. Ecology 86: 308-319. https://doi. org $/ 10.1890 / 03-0583$

IPCC. 2013. The physical science basis. Contribution of Working Group I to the Fifth Assessment Report of the Intergovernmental Panel on Climate Change (Stocker TF, Qin D, Plattner G-K, Tignor M, Allen SK, Boschung J, Nauels A, Xia Y, Bex V, Midgley PM, Eds.). Cambridge University Press, Cambridge, United Kingdom and New York, NY, USA, 1535 pp. Jain S, Lall U. 2001. Floods in a changing climate: Does the past represent the future? Water Resources Research 37 : 3193-3205. https://doi.org/10.1029/2001WR000495

Jung M, Reichstein M, Ciais P, Seneviratne SI, Sheffield J, Goulden ML. 2010. Recent decline in the global land evapotranspiration trend due to limited moisture 
supply. Nature 467: 951-954. https://doi.org/10.1038/ nature09396

Karl TR, Jones PD, Knight RW, Kukla G, Plummer N, Razuvayev V, Gallo KP, Lindseay J, Charlson JR, Peterson TC. 1993. Asymmetric trends of daily maximum and minimum temperature. Bulletin of the American Meteorological Society 74: 1007-1024. https://doi.org/10.1175/1520-0477(1993)074<1007 :ANPORG $>2.0 . \mathrm{CO} ; 2$

King'uyu S, Ogallo L, Anyamba E. 2000. Recent trends of minimum and maximum surface temperatures over Eastern Africa. Journal of Climate 13): 2876-2886. https://doi.org/10.1175/1520-0442(2000)013<2876:RTOMAM $>2.0 . \mathrm{CO} ; 2$

Kizza M, Rodhe A, Xu C-Y, Ntale HK, Halldin S. 2009. Temporal rainfall variability in the Lake Victoria Basin in East Africa during the twentieth century. Theoretical and Applied Climatolology 98: 119-135. https://doi. org/10.1007/s00704-008-0093-6

Kruger C, Shongwe S. 2004. Temperature trends in South Africa: 1960-2003. International Journal of Climatology 24: 1929-1945. https://doi.org/10.1002/joc.1096

Loik ME, Breshears DD, Lauenroth WK, Belnap J. 2004 A multi-scale perspective of water pulses in dryland ecosystems: Climatology and ecohydrology of the western USA. Oecologia 141: 269-281. https://doi. org/10.1007/s00442-004-1570-y

Ly M, Traore SB, Alhassane A, Sarr B. 2013. Evolution of some observed climate extremes in the West African Sahel. Weather and Climate Extremes 1: 19-25. https:// doi.org/10.1016/j.wace.2013.07.005

MacDonald M, Calow RC, MacDonald DMJ, Darling WG, Dochartaigh B. 2009. What impact will climate change have on rural groundwater supplies in Africa? Hydrological Sciences Journal 54: 690-703. https:// doi.org/10.1623/hysj.54.4.690

MacKellar N, New M, Jack C. 2014. Observed and modelled trends in rainfall and temperature for South Africa: 1960-2010. South African Journal of Science 110: 1-1., https://doi.org/10.1590/sajs.2014/20130353

Maidment RI, Allan RP, Black E. 2015. Recent observed and simulated changes in precipitation over Africa. Geophysical Research Letters 42: 8155-8164. https:// doi.org/10.1002/2015GL065765

Martens B, Miralles DG, Lievens H, van der Schalie R, de Jeu RAM, Fernández-Prieto D, Beck HE, Dorigo WA, Verhoest NEC. 2017. GLEAM v3: Satellitebased land evaporation and root-zone soil moisture.
Geoscientific Model Development 10: 1903-1925. https://doi.org/10.5194/gmd-10-1903-2017

Martens B, Waegeman W, Dorigo WA, Verhoest NEC, Miralles DG. 2018. Terrestrial evaporation response to modes of climate variability. npj Climate and Atmospheric Science 1: 43. https://doi.org/10.1038/ s41612-018-0053-5

McLeod NH. 1976. Dust in the Sahel: Cause of drought? In: The politics of natural disaster (Glantz M, Ed.). Praeger Publishers, New York, 3-13.

McVicar TR, Roderick ML, Donohue RJ, Li LT, Van Niel TG, Thomas A, Grieser J, Jhajharia D, Himri Y, Mahowald NM, Mescherskaya AV, Kruger AC, Rehman S, Dinpashoh Y. 2011. Global review and synthesis of trends in observed terrestrial near-surface wind speeds: Implications for evaporation. Journal of Hydrology 416-417: 182-205. https://doi.org/10.1016/j. jhydrol.2011.10.024

Mekasha A, Tesfaye K, Duncan AJ. 2014. Trends in daily observed temperature and precipitation extremes over three Ethiopian eco-environments. International Journal of Climatology 34: 1990-1999. https://doi. org/10.1002/joc.3816

Milly PCD. 1994. Climate, soil water storage and the average annual water budget. Water Resources Research 30: 2143-2156. https://doi.org/10.1029/94WR00586

Miralles DG, Holmes TRH, de Jeu RAM, Gash JH, Meesters AGCA, Dolman AJ. 2011. Global land-surface evaporation estimated from satellite-based observations. Hydrology and Earth System Sciences 15: 453-469. https://doi.org/10.5194/hess-15-453-2011

Morishima W, Akasaka I. 2010. Seasonal trends of rainfall and surface temperature over Southern Africa. African Study Monographs 40: 67-76.

Moron V, Oueslati B, Pohl B, Rome S, Janicot S. 2016. Trends of mean temperatures and warm extremes in northern tropical Africa (1961-2014) from observed and PPCA-reconstructed time series. Journal of Geophysical Research: Atmospheres 121: 5298-5319. https://doi.org/10.1002/2015JD024303

Mubialiwo A, Onyutha C, Abebe A. 2020. Historical rainfall and evapotranspiration changes over Mpologoma catchment in Uganda. Advances in Meteorology 2020 (8870935): 1-19. https://doi. org/10.1155/2020/8870935

Muhlenbrunch-Tegen A. 1992. Long-term surface temperature variations in South Africa. South African Journal of Science 88: 197-205. 
Nashwan MS, Shahid S. 2019. Spatial distribution of unidirectional trends in climate and weather extremes in Nile river basin. Theoretical and Applied Climatology 137: 1181-1199. https://doi.org/10.1007/s00704-0182664-5

Nashwan MS, Shahid S, Abd Rahim N. 2019. Unidirectional trends in annual and seasonal climate and extremes in Egypt. Theoretical and Applied Climatology 136: 457-473. https://doi.org/10.1007/s00704018-2498-1

Neumann R, Jung G, Laux P, Kunstmann H. 2007. Climate trends of temperature, precipitation and river discharge in the Volta Basin of West Africa. International Journal of River Basin Management 5: 17-30. https://doi.org/ 10.1080/15715124.2007.9635302

Niang I, Ruppel OC, Abdrabo MA, Essel A, Lennard C, Padgham J, Urquhart P. 2014. Africa. In: Climate Change 2014: Impacts, Adaptation, and Vulnerability. Part B: Regional Aspects. Contribution of Working Group II to the Fifth Assessment Report of the Intergovernmental Panel on Climate Change (Barros VR, Field CB, Dokken DJ, Mastrandrea MD, Mach KJ, Bilir TE, Chatterjee M, Ebi KL, Estrada YO, Genova RC, Girma B, Kissel ES, Levy AN, MacCracken S, Mastrandrea PR, White LL, Eds.). Cambridge University Press, Cambridge, United Kingdom and New York, NY, USA, 1199-1265.

Nicholson SE. 2000. The nature of rainfall variability over Africa on time scales of decades to millennia. Global Planetary Change 26: 137-158. https://doi.org/10.1016/ S0921-8181(00)00040-0

Nicholson SE, Selato JC. 2000. The influence of La Niñna on African rainfall. International Journal of Climatology 20: 1761-1776. https://doi. org/10.1002/1097-0088(20001130)20:14<1761::AIDJOC580>3.0.CO;2-W

Nyeko-Ogiramoi P, Willems P, Ngirane-Katashaya G. 2013. Trend and variability in observed hydrometeorological extremes in the Lake Victoria basin. Journal of Hydrology 489: 56-73. https://doi.org/10.1016/j. jhydrol.2013.02.039

Oloruntade J, Mohammad TA, Ghazali AH, Wayayok A. 2016. Spatial and temporal trends in mean, maximum and minimum temperature in the Niger-South basin, Nigeria. Malaysian Journal of Civil Engineering 28: 365-381. https://doi.org/10.11113/mjce.v28n3.431

Onyutha C, Tabari H, Taye MT, Nyandwaro GN, Willems P. 2016. Analyses of rainfall trends in the Nile River basin. Journal of Hydro-environment Research 13: 3651. https://doi.org/10.1016/j.jher.2015.09.002

Onyutha C. 2016a. Statistical uncertainty in hydrometeorological trend analyses. Advances in Meteorogy 2016 (8701617): 1-26. https://doi.org/10.1155/2016/8701617 Onyutha C. 2016b. Identification of subtrends from hydro-meteorological series. Stochastic Environmental Research Risk Assessment 30: 189-205. https://doi. org/10.1007/s00477-015-1070-0

Onyutha C. 2016c. Statistical analyses of potential evapotranspiration changes over the period 1930-2012 in the Nile River riparian countries. Agricultural and Forest Meteorology 226-227: 80-95. https://doi.org/10.1016/j. agrformet.2016.05.015

Onyutha C. 2018a. Trends and variability in African long-term precipitation. Stochastic Environmental Research and Risk Assessment 32: 2721-2739. https:// doi.org/10.1007/s00477-018-1587-0

Onyutha C. 2018b. African crop production trends are insufficient to guarantee food security in the sub-Saharan region by 2050 owing to persistent poverty. Food Security 10 : 1203-1219. https://doi.org/10.1007/s12571-018-0839-7

Onyutha C. 2019. African food insecurity in a changing climate: The roles of science and policy. Food Energy Security 8 (e00160): 1-18. https://doi.org/10.1002/ fes 3.160

Onyutha C. 2020. Analyses of rainfall extremes in East Africa based on observations from rain gauges and climate change simulations by CORDEX RCMs. Climate Dynamics 54: 4841-4864. https://doi.org/10.1007/ s00382-020-05264-9

Ozer P, Mahamoud A. 2013. Recent extreme precipitation and temperature changes in Djibouti city (1966-2011). Journal of Climatology 2013 (e928501): 1-8, https:// doi.org/10.1155/2013/928501

Sen PK. 1968. Estimates of the regression coefficient based on Kendall's tau. Journal of the American Statistical Association 63: 1379-1389. https://doi.org/10.1080/0 1621459.1968.10480934

Serdeczny O, Adams S, Baarsch F, Coumou D, Robinson A, Hare W, Schaeffer M, Perrette M, Reinhardt J. 2016. Climate change impacts in sub-Saharan Africa: From physical changes to their social repercussions. Regional Environment Change 17: 1585-1600. https:// doi.org/10.1007/s10113-015-0910-2

Smith SD, Monson RK, Anderson JE. 1997. Physiological Ecology of North American Desert Plants. Springer-Verlag, Berlin, 286 pp. 
Tacoli C. 2009. Crisis or adaptation? Migration and climate change in a context of high mobility. Environment and Urbanization 21: 513-525. https://doi. org/10.1177/0956247809342182

Theil H. 1950. A rank-invariant method of linear and polynomial regression analysis. Nederlandse Akademie van Wetenschappen, Series A 53: 386-392. https://doi. org/10.1007/978-94-011-2546-8_20

Trenberth E, Fasullo JT, O’Dell C, Wong T. 2010. Relationships between tropical sea surface temperatures and top-of-atmosphere radiation. Geophysical Research Letters 37: 1-5. https://doi.org/10.1029/2009GL042314

Tucker CJ, Dregne HE, Newcomb WW. 1991. Expansion and contraction of the Sahara Desert from 1980 to 1990. Science 253: 299-301. https://doi.org/10.1126/ science.253.5017.299

Tucker CJ, Nicholson SE. 1999. Variations in the size of the Sahara Desert from 1980 to 1997. Ambio 28: 587-591.

Usodomenech JL, Villacampaesteve Y, Stubingmartinez G, Karjalainen T, Ramo MP. 1995. MARIOLA: A model for calculating the response of Mediterranean bush ecosystem to climatic variations. Ecologocial Modelling 80: 113-129. https://doi.org/10.1016/03043800(94)00052-J

Warner K. 2010. Global environmental change and migration: governance challenges. Global Environmental Change 20: 402-413. https://doi.org/10.1016/j.gloenvcha.2009.12.001

Wilske B, Kwon H, Wei L, Chen S, Lu N, Lin G, Xie J, Guan W, Pendall E, Ewers BE, Chen J. 2009. Evapotranspiration (ET) and regulating mechanisms in two semiarid Artemisia-dominated shrub steppes at opposite sides of the globe. Journal of Arid Environments 74: 1461-1470. https://doi.org/10.1016/j.jaridenv.2010.05.013

Young MH, Caldwell TG, Meadows DG, Fenstermaker LF. 2009. Variability of soil physical and hydraulic properties at the Mojave Global Change Facility, Nevada: Implications for water budget and evapotranspiration. Journal of Arid Environments 73: 733-744. https://doi. org/10.1016/j.jaridenv.2009.01.015

Zhou L. 2016. Desert amplification in a warming climate. Scientific Reports 6 (31065). https://doi.org/10.1038/ srep31065 